\title{
Evaluation of the localization and biological effects of PAMAM G3 dendrimer-biotin/pyridoxal conjugate as $\mathrm{HaCaT}$ keratinocyte targeted nanocarrier
}

\author{
Magdalena Szuster ${ }^{1}$, Łukasz Uram ${ }^{1 \otimes}$, Aleksandra Filipowicz-Rachwał², Stanisław Wołowiec ${ }^{3}$ \\ and Elżbieta Wałajtys-Rode ${ }^{4}$ \\ ${ }^{1}$ Faculty of Chemistry, Rzeszow University of Technology, Rzeszów, Poland; ${ }^{2}$ Faculty of Medical Sciences, Rzeszow University of Information \\ Technology and Management, Rzeszów, Poland; ${ }^{3}$ Centre for Innovative Research in Medical and Natural Sciences, Faculty of Medicine, Univer- \\ sity of Rzeszow, Rzeszów, Poland; “Department of Drug Technology and Biotechnology, Faculty of Chemistry, Warsaw University of Technology, \\ Warsaw, Poland
}

Recognition of the molecular mechanisms of keratinocyte participation in normal skin homeostasis and in pathogenesis may lead to creation of more effective tools for topical application of cosmetics, cosmeceutics and drugs to a particular location within the skin for prevention and therapy of many skin disorders and diseases. For this purpose, the PAMAM G3 dendrimer with amide linkages of 9 biotin molecules and 10 molecules of pyridoxal phosphate (BC-PAMAM) was constructed, and its biological properties and cellular uptake and localization were investigated in the $\mathrm{HaCaT}$ keratinocytes. BC-PAMAM is nontoxic for HaCaT cells, as estimated by two assays (Neutral Red and tetrazolium salt reduction, $\mathrm{XTT}$ ), and revealed low apoptosis induction at up to 50 $\mu \mathrm{M}$ concentration. Fluorescent labeled BC-PAMAM accumulates in $\mathrm{HaCaT}$ cells with high efficiency in a concentration-dependent manner. Its mitochondrial localization, estimated as Mander's colocalization coefficient, is substantially lower than the native PAMAM, and that correlates with its cytotoxicity. The only undesirable, but significant inhibitory effect on cell mobility, evaluated by the wound healing test, was observed at $10 \mu \mathrm{M} B C-$ PAMAM. The important anti-inflammatory action of BCPAMAM was clearly documented by decreased production of total IL-1a, assayed with an ELISA test with unstimulated and stimulated by bacterial antigens (LPS and GroEL) HaCaT cells. Thus, it is expected that the biotin pyridoxal phosphate conjugated PAMAM may be considered as a potential carrier for safe delivery of vitamins and drugs into the epidermis.

Key words: vitamin B PAMAM G3 dendrimer bioconjugate, $\mathrm{HaCaT}$ cells, cytotoxicity, cellular localization, IL-1a, TNF-a

Received: 12 January, 2019; revised: 10 February, 2019; accepted: 19 March, 2019; available on-line: 09 April, 2019

Đe-mail: uram@prz.edu.pl

Acknowledgements of Financial Support: This work was supported by grant 2014/13/D/NZ3/02825 from the National Science Centre, Poland.

Abbreviations: PAMAM G3, third generation poly(amidoamine) dendrimer; BC-PAMAM, G3 PAMAM conjugated with vitamin B6 and B7; $\mathrm{HaCaT}$, human immoratlized keratinocytes; IL-1a, interleukin 1a; LPS, E. coli lipopolisaccharide strain 0111:B4; GroEL, E. coli protein (Hsp60); KC, keratinocytes; PMA, phorbol ester; TNF-a, tumor necrosis factor a

\section{INTRODUCTION}

Increasing prevalence of the human skin homeostasis disturbance due to environmental hazards has resulted in intensification of the search for effective protection and treatment strategies. It has been already established that the largest human organ, the skin, constitutes not only a passive protective barrier, but being a network of specific effector cells, extracellular matrix and molecular mediators, creates a skin endocrine-immune system comprising all skin compartments (Abdallah et al., 2017). Recently, it has been proven that the epidermis has an important and specific role in initiation and programming of the skin inflammatory and immune response under normal and pathological conditions (Mann et al., 2012). Keratinocytes, which constitute almost $95 \%$ of the epidermis, were shown to realize the first-line of immune defense by stimulation of innate mechanisms and promotion of an adaptive response, and are considered as the skin immune sentinels (Nestle et al., 2009; GutowskaOwsiak \& Ogg, 2012). Keratinocytes have been recognized as important in priming and development of multiple skin chronic inflammatory, autoimmune and proliferative mechanisms. Recently, an important keratinocyte involvement in premature photo ageing (Imokawa et al., 2015), allergic atopic and contact dermatitis (Honda \& Kabashima, 2016; Komine, 2009; Hoffmann \& Schmidt, 2013), proliferative disorders psoriasis (Dombrowski et al., 2011) and cancer (Karimkhani et al., 2015) has been proven. Molecular mechanisms of the keratinocyte response to the external stimuli and interaction with other cellular skin components are still under investigation. Constitutive and inducible production of a variety of biologically active molecules by keratinocytes, including antimicrobial peptides, cytokines and growth factors, depends on the stimuli and is described in several reviews (Gröne, 2002; Abdallach et al., 2017 and ref. therein). Recognition of the molecular mechanisms of keratinocyte participation in normal skin homeostasis and in pathogenesis may lead to creation of more effective tools for prevention and therapy of many skin disorders and diseases. One of the major subjects of many investigations is topical application of cosmetics, cosmeceutics and drugs, and their distribution to a particular location within the skin. 
In search for safe and efficient methods, application of targeted nanomolecules, including dendrimers, has been investigated with many positive results. Among them, low generation dendrimers, e.g. PAMAM G3, G4 and G5, have been considered as very promising targeted nanocarriers (Jędrych et al., 2014; Labieniec-Watala \& Watala, 2015). Particular attention has been given to the B vitamin group, i.e. biotin (vitamin B7) and pyridoxal (vitamin B6) as targeting molecules. It has been known that both vitamins are necessary for vital functions of all mammalian cells. Biotin is involved in important metabolic pathways, such as gluconeogenesis, fatty acid synthesis, and amino acid catabolism, and as a cofactor in the transfer of $\mathrm{CO}_{2}$ groups to various target macromolecules, while pyridoxal participates in regeneration of tetrahydrofolate and in glutathione biosynthesis. Both vitamins play important roles in the energy metabolism (Depeind et al., 2006a; Depeind et al., 2006b). Further progress in biotin function investigation revealed its epigenetic properties and a role in cell signaling (Kothapalli et al., 2005; Zempleni, 2005; Zempleni et al., 2009) and in defense against reactive oxygen species ( $\mathrm{Li}$ et al., 2014). Investigation of biotin conjugated carriers had initiated from an observation that many aggressive cancer cell lines present overexpression of the main transporter for biotin - the sodium dependent multivitamin transporter (SMVT) (Maiti \& Paira, 2018 and ref.). Majority of cells, including keratinocytes, expresses two carriers for biotin transport: SMVT and the proton-dependent monocarboxylate transporter 1 (MCT-1) (Daberkow et al., 2003; Grafe et al., 2003; Azhar et al., 2015), which are considered in construction of the nanocarriers for diagnosis and treatment of the skin disorders (Yang et al., 2009; Dianzani et al., 2014). Realization of that aim requires interdisciplinary investigations. This also includes the choice of a proper experimental model in vitro, which means choosing a proper cell line and the targeting molecule.

Use of human keratinocytes (KC) from skin biopsies as a model for in vitro studies on biological effects of various natural and synthetic substances on epidermis is limited due to the donor variability, a short culture lifetime, and variations between passages. For many researchers, application of $\mathrm{HaCaT}$ keratinocytes, i.e. a human monoclonal, spontaneously immortalized human keratinocyte line, has been a matter of choice due to their lower variability than $\mathrm{KC}$, long term growth in cultures and no spontaneous tumorigenic properties.

It has been shown that the HaCaT cells can reversibly differentiate into stratified epidermal structure under specific stimulation in vitro and are able to reconstitute proper epidermis after transplantation in vivo. Also, they undergo inflammatory and allergic responses with production of specific cytokines. However, more detailed studies gathered various data concerning their biological response when compared to primary KC. Investigation of the $\mathrm{HaCa}$ T cells as a model for induction of cancer revealed that a strong cancer promotor, 12-O-tetradecanoylphorbol 13-acetate (TPA), indicated a defective MEK/ERK signaling in the HaCaT cells that compromises their use as a human in vitro skin carcinogenesis model (Ridd et al., 2010). The use of HaCaT cells as a response model for development of inflammatory or hypersensitivity reactions is still under discussion with many contradictory opinions (Stein et al., 1997; Köllisch et al., 2005; Hoffmann \& Schmidt, 2013; Colombo et al., 2017).

The aim of our studies was to evaluate the biological effects (cytotoxicity, apoptosis, cell mobility) of vitamin
B6 and B7 substituted G3 PAMAM dendrimer (BCPAMAM), its subcellular location and immunological properties in the HaCaT cells in vitro, as a possible carrier of vitamins and drugs to the epidermis.

\section{MATERIALS AND METHODS}

Synthesis of PAMAM and BC-PAMAM dendrimers. Synthesis of the native PAMAM G3 (PAMAM) dendrimer and its bioconjugate substituted with nine biotin molecules (linked via an amide bond) and ten pyridoxal (PL) molecules (linked via an aldimine bond), G39B10P (BC-PAMAM), was performed as described earlier (Uram et al., 2013). The native fluorescent PAMAM and bioconjugate BC-PAMAM labeled with FITC were prepared according to a published protocol (Filipowicz \& Wołowiec, 2011).

Materials. Trypsin-EDTA solution, phosphate-buffered saline (PBS) with and without magnesium and calcium ions, hydrocortisone, XT'T sodium salt (2,3-bis[2methoxy-4-nitro-5-sulfophenyl]-2H-tetrazolium-5-carboxanilide inner salt), phenazine methosulfate PMS (Nmethyl dibenzopyrazine methyl sulfate), $0.33 \%$ neutral red solution (NR) (3-amino-m-dimethylamino-2-methylphenazine hydrochloride), $0.4 \%$ trypan blue solution in PBS, E. coli lipopolisaccharide strain 0111: B4 (LPS), phorbol ester (phorbol-12-myristate-13-acetate, PMA) were provided by Sigma-Aldrich (St Louis, MO, USA). Fluorescent marker DAPI (4',6-diamidino-2-phenylindole, dihydrochloride), Mito'Tracker ${ }^{\circledR}$ Deep Red FM and Endogenous Biotin-Blocking Kit, were purchased from Thermo Fisher Scientific (Waltham, MA, USA). Cell culture devices were from Corning Incorporated (Corning, NY, USA), Nunc (Roskilde, Denmark) or Greiner BioOne (Greiner Bio-One GmbH, Germany). Dulbecco's Modified Eagle's Medium (DMEM), fetal bovine serum (FBS), penicillin and streptomycin solutions were purchased from American Type Culture Collection (ATCC, Manassas, VA, USA). E. coli GroEL protein (Hsp60) was from Abcam. Monoclonal antibody against PARP-1 (Asp 114) marked with AlexaFluor ${ }^{\circledR} 647$ were from BD PharmingenTM. Human IL-1 alpha / IL-1F1 DuoSet ELISA kit, Human TNF-alpha DuoSet ELISA kit, ready reagents and tiles DuoSet Ancillary Reagent Kit were from R\&D Systems. Human immortalized keratinocytes (HaCaT) were obtained from the Cell Lines Service $\mathrm{GmbH}$ (Germany).

Cell culture. HaCaT cells (doubling time 24 hours), were cultured in a complete DMEM medium supplemented with $10 \%$ fetal bovine serum (FBS), $100 \mathrm{U} / \mathrm{mL}$ penicillin and $100 \mu \mathrm{g} / \mathrm{mL}$ streptomycin, in a humidified $95 \%$ air and $5 \% \mathrm{CO}_{2}$ atmosphere at $37^{\circ} \mathrm{C}$, with replacing the fresh medium every 2-3 days. Cells were passaged at $70-85 \%$ confluence using $0.25 \%$ trypsin-EDTA in PBS ( $\mathrm{Ca}^{2+}$ and $\mathrm{Mg}^{2+}$ free). Cell morphology was assayed using a Nikon TE2000S Inverted Microscope (Tokyo, Japan) with phase contrast. The number and viability of cells were estimated by a Trypan blue exclusion test with Automatic Cell Counter TC20 TM (Bio-Rad Laboratories, Hercules, CA, USA). Working solutions of the dendrimers were prepared in a culture medium containing 2\% FBS.

Cytotoxicity assays. Cells were seeded in flat-bottom 96-well culture plates at a density of $4 \times 10^{4}$ cells/well and allowed to attach for 24 hours. The working solutions of dendrimers in the culture medium were prepared from a sterile $1 \mathrm{mM}$ stock solution in $\mathrm{H}_{2} \mathrm{O}$ (syringe filters, 0.22 $\mu \mathrm{m})$. Cells were treated with dendrimers in concentra- 
tions ranging from 0 to $100 \mu \mathrm{M}$. After $24 \mathrm{~h}$ incubation, the medium was removed and replaced by the following solutions:

Neutral Red assay: 2\% NR solution in the culture medium was added $(100 \mu \mathrm{L} /$ well $)$, and the cells were incubated $\left(1.5 \mathrm{~h}, 37^{\circ} \mathrm{C}\right)$ and washed once with PBS. After addition of a fixative $\left(50 \%\right.$ ethanol, $49 \% \mathrm{H}_{2} \mathrm{O}, 1 \%$ glacial acetic acid, $100 \mu \mathrm{L} /$ well $)$ the plates were shaken (500 rpm, 15 min., RT). Absorbance was measured at $540 / 620 \mathrm{~nm}$ with a microtiter plate reader $\mu$ QuantTM (Bio'Tek Instruments, Inc. Winooski, VT, USA) against a blank (the fixative mixture). The results are shown as a median of three replicates from four independent experiments.

For XTT assay: mixture of $5 \mathrm{mM}$ XTT and $25 \mu \mathrm{M}$ PMS in the medium $(150 \mu \mathrm{L} /$ well $)$ was added, and after $2 \mathrm{~h}$ incubation $\left(37^{\circ} \mathrm{C}\right)$ absorbance was measured at $450 / 620 \mathrm{~nm}$ against a blank sample $(150 \mu \mathrm{L}$ medium containing XTT and PMS). The results are shown as a median of three replicates from four independent experiments.

Apoptosis assay. As apoptosis marker, the PARP-1 (Asp 114) assay was used with antibodies labeled with AlexaFluor ${ }^{\circledR}$ 647. HaCaT cells $\left(4 \times 10^{4}\right.$ cells/well $)$ were cultured and treated for $24 \mathrm{~h}$ with dendrimers at concentrations of $0,5,10$ and $50 \mu \mathrm{M}$, similarly as for the cytotoxicity assay. The assay was performed as previously described (Niziol et al., 2015).

Cell migration assay (scratch wound healing assay). Cells were cultured in 24 -well plates at $2 \times 10^{5}$ cell/ well $\left(24 \mathrm{~h}, 37^{\circ} \mathrm{C}\right)$ to confluence. Wound healing assay was performed as described (Uram et al., 2017).

Cellular accumulation of FITC labelled PAMAM and BC-PAMAM. Cells seeded at a density of $4 \times 10^{4}$ cells/well in 96-well microtiter plates were cultured for $24 \mathrm{~h}$ and treated with FITC labeled dendrimers (PAMAM or BC-PAMAM) for $24 \mathrm{~h}$ at the concentrations ranging from 0 to $50 \mu \mathrm{M}$, washed with PBS and stained with $600 \mathrm{nM}$ DAPI solution. The fluorescence signal was read at 485/530 nm for FITC, and at 360/460 nm for DAPI, using Infinite M200 PRO Multimode Microplate Reader (TECAN Group Ltd., Switzerland). The DAPI fluorescence signals were used to estimate the number of cells in each well and to calculate respective fluorescent signal intensity. The results are shown as medians of relative fluorescence units of three replicates from four independent experiments.

Subcellular localization of PAMAM and BCPAMAM. Nuclei penetration: $\mathrm{HaCaT}$ cells were cultured on microscope chamber slides (Nunc, Denmark) for $48 \mathrm{~h}$ at a density of $4 \times 10^{4}$ cells in $400 \mu \mathrm{L}$ of complete medium. FITC labeled PAMAM or BC-PAMAM dendrimers were added at 1 to $50 \mu \mathrm{M}$ concentrations $(200 \mu \mathrm{L} /$ well). After $24 \mathrm{~h}$ incubation and washing ( $2 \times$ PBS), the cells were fixed with $3.7 \%$ formaldehyde for 15 minutes and stained with $600 \mathrm{nM}$ DAPI solution in PBS (1 h, RT). Twelve randomly selected images from each well were collected using a confocal microscope (Olympus FV10i, Tokyo, Japan) at 488/530 nm for FITC, and 405/461 nm for DAPI. Images were collected in the Z-axis position at the largest nuclear cross section area. Pinhole was set for 1 AU (airy unit) and the obtained images had an optical section thickness of approximately $1.02 \mu \mathrm{m}$. Images were analyzed with the ImageJ software using the JACoP plugin, and the Mander's colocalization coefficient $(M)$ was calculated. The results were presented as the percentage of the overlap of green channel signal (dendrimers) with blue channel signal (nuclei) (M1). M coefficient ranges from 0 to 1 , where 0 means no colocalization (no overlap of signals), and 1 means complete coverage of two signals (full colocalization).

Colocalization with mitochondria: $\mathrm{HaCaT}$ cells were cultured and treated with fluorescently labeled dendrimers as above. After washing with the culture medium, mitochondria were stained with $100 \mathrm{nM}$ Mito'Tracker ${ }^{\circledR}$ Deep Red FM solution $\left(30\right.$ min., $37^{\circ} \mathrm{C}$ ) according to the manufacturer's protocols. After washing with PBS $(3 \times)$, the cells were fixed and stained with DAPI as described for the nuclei. Images were obtained in three channels using an Olympus FV10i confocal microscope: at 405/461 nm for DAPI, 488/530 nm for FITC-labeled dendrimers, and 644/665 nm for MitoTracker. Image analysis was performed with the ImageJ software, using the JACoP plugin to estimate the Mander's coefficient that indicates the degree of green signal (dendrimers) overlapping with the red signal (mitochondria) (M2).

Cytokine production. HaCaT cells were cultured in 24-well plate at a density of $2 \times 10^{5}$ cells/well in $500 \mu \mathrm{L}$ of DMEM medium $\left(24 \mathrm{~h}, 37^{\circ} \mathrm{C}\right)$ to reach confluence (Phillips et al., 1995), and treated with dendrimers at non cytotoxic 0.1 or $1.0 \mu \mathrm{M}$ concentrations with or without stimulants. The following stimulants were used: E. coli LPS strain 0111: B4 in PBS at a final concentration of $100 \mathrm{ng} / \mathrm{ml}$, PMA diluted in DMSO at a final concentration of $50 \mathrm{ng} / \mathrm{mL}$, and E. coli GroEL (Hsp60) protein at a final concentration of $1 \mu \mathrm{g} / \mathrm{mL}$. LPS has a strong immunogenic effect, stimulating cells involved in the innate immune response through the TLR4 receptors (PalssonMcDermott \& O’Neill, 2004), PMA induces a pro-inflammatory response of cells in vitro and is recognized as a tumor promoter (Emerit \& Cerutti, 1981; Lepe-Zuniga \& Gery, 1984) and GroEL, a protein belonging to the Hsp family, is involved in the pathogenesis of many inflammatory reactions of immune cells and keratinocytes (van Eden et al., 2003; Marcatili et al., 1997). Solutions of dendrimers and the stimulating substances were prepared in a medium with $2 \%$ FBS, except for PMA samples that also contained DMSO (final concentration did not exceed $0.1 \%$ ). The cells were treated for 12 or 24 $\mathrm{h}$ with the respective media (control), dendrimers alone, stimulants alone or the dendrimer and stimulant mixture. For assays, the cell cultures with medium were disrupted by double freeze-thawing cycle at $-80^{\circ} \mathrm{C}$, lysates were collected by centrifugation $\left(10000 \mathrm{rpm}, 5 \mathrm{~min}, 4^{\circ} \mathrm{C}\right)$ and kept at $-20^{\circ} \mathrm{C}$.

ELISA assay. The total amount (cellular and secreted) of IL- $1 \alpha$ and TNF- $\alpha$ cytokines were determined with human IL-1 $\alpha /$ IL-1F1 DuoSet ELISA kits, Human TNF- $\alpha$ DuoSet ELISA and DuoSet Ancillary Reagent Kit from R\&D Systems, according to the manufacturer's protocol. Shortly: wells were coated with a capture antibody, i.e. anti-IL- $1 \alpha$ or anti-TNF- $\alpha$ (1:120 in PBS), overnight at RT. Cytokine standards were prepared in the range of $7.8-500 \mathrm{pg} / \mathrm{ml}$ for IL- $1 \alpha$, and $15.6-1000$ $\mathrm{pg} / \mathrm{ml}$ for $\mathrm{TNF}-\alpha$. In order to block the non-specific signal from the dendrimers containing biotin, a kit for blocking endogenous biotin (Endogenous Biotin-Blocking Kit, ThermoFisher) was applied. Shortly: to the samples containing BC-PAMAM, the Streptavidin Reagent solution was added $(50 \mu \mathrm{L} /$ well $)$ and incubated $(20 \mathrm{~min}$., RT). After washing (3×, PBST $\left(0.05 \%\right.$ Tween $^{\circledR} 20$ in PBS)), the Biotin Reagent was added (50 $\mu \mathrm{L} /$ well $)$ and cells were incubated (20 min., RT). Both cytokine assays were performed by addition of the mixture of respective biotinylated detection antibodies (Detection Antibody: Biotinylated Goat Anti- Human IL- $1 \alpha$ or TNF- $\alpha$ ) with streptavidin-conjugated horseradish peroxidase (Strepta- 


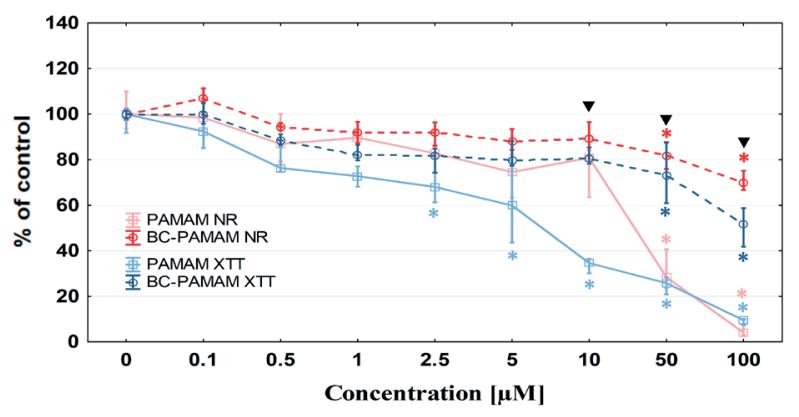

Figure 1. Cytotoxicity of PAMAM and BC-PAMAM dendrimers for $\mathrm{HaCaT}$ cells after $24 \mathrm{~h}$ treatment, measured by NR (red lines) and XTT (blue lines) tests.

Median results from three replicates of four independent experiments. Error bars express $25 \%$ and $75 \%$ quartiles. ${ }^{*}$ Indicate statistical significance $(P<0.05)$ against control (Kruskal-Wallis test). $\nabla$ Statistically significant difference between PAMAM and BCPAMAM treated cells in both XTT and NR assays $(P<0.05$, Mann Whitney $\mathrm{U}$ test).

vidin-HRP), according to manufacturer's protocol. Enzymatic reaction was developed with tetramethylbenzidine (20 min., RT) and terminated with $50 \mu \mathrm{L}$ of $2 \mathrm{M} \mathrm{H}_{2} \mathrm{SO}_{4}$. Absorbance was measured with uQuantTM spectrophotometer (BioTek) at $450 \mathrm{~nm} / 540 \mathrm{~nm}$. Total cytokine concentrations were calculated from the standard curve prepared using the Microsoft Excel software. The results are presented as a median of cytokine concentrations of six replicates from three independent experiments. The sensitivity of the test was $2 \mathrm{pg} / \mathrm{ml}$ for IL- $1 \alpha$, and $6 \mathrm{pg} /$ $\mathrm{ml}$ for $\mathrm{TNF}-\alpha$.

Statistical analysis. Statistical analysis was performed using non-parametric tests due to the lack of normal distribution of the data (estimated using the Shapiro-Wilk test). In order to compare the effect of dendrimers with the untreated control groups, the Kruskal-Wallis test was used, while the Mann-Whitney $U$ test was used to assess the significance of differences between the effects of PAMAM and BC-PAMAM. The level of significance was set at $P<0.05$. Calculations were performed using Statistica 12 software (StatSoft).

\section{RESULTS AND DISCUSSION}

\section{Cytotoxicity}

Cytotoxicity data for PAMAM and BC-PAMAM in the concentration range of $0-100 \mu \mathrm{M}$ are presented in Fig. 1. The low but significant cytotoxicity of bioconjugate for HaCaT cells (10-20\% of dead cells) was seen in both assays at $<50 \mu \mathrm{M}$ concentrations, whereas unsubstituted PAMAM was significantly cytotoxic at $50 \mu \mathrm{M}$ in the NR assay and at $2.5 \mu \mathrm{M}$ in the XT'T assay. The observed difference in cytotoxicity of dendrimers measured with different assays points to various interactions of either dendrimer with the HaCaT keratinocytes. NR is a weak cationic dye that penetrates the cellular membranes and accumulates intracellularly in the lysosomes of viable cells. BC-PAMAM did not disturb the ability of HaCaTs for NR uptake into lysosomes even at high concentrations $(>50 \mu \mathrm{M})$ when compared to the native PAMAM effect that is significantly stronger at these concentrations (Fig. 1). The XT'T dye reduction takes place on the cell surface due to the transmembrane electron transport in which mitochondrial oxidoreductases play a crucial role. It has been suggested that the XTT assay
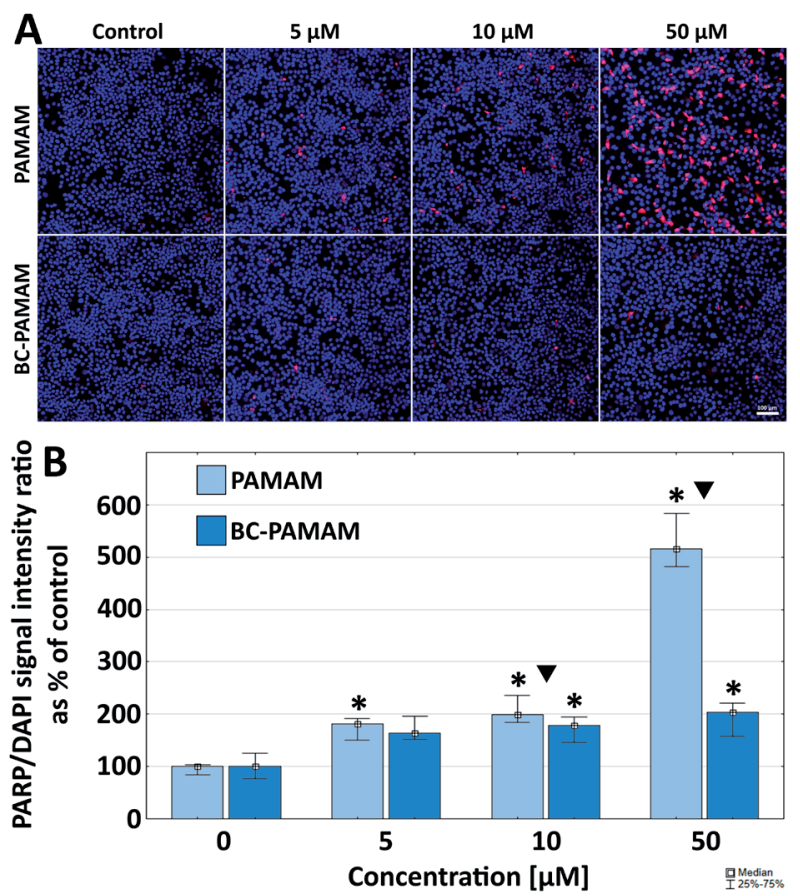

Figure 2. Apoptosis in HaCaT cells caused by $24 \mathrm{~h}$ treatment with PAMAM and BC-PAMAM dendrimers.

Cells were stained with anti-PARP antibodies (Asp 214) coupled to AlexaFluor 647 and DAPI dyes. (A) Images from confocal microscopy showing expression of the PARP-1 apoptosis marker in $\mathrm{HaCaT}$ cells. Blue signal, DAPI stained cell nuclei; pink signal, fluorescently labeled anti-PARP-1 antibodies. (B) The ratio of the AlexaFluor ${ }^{\oplus} 647$ to DAPI fluorescence signals is shown as medians. Error bars: bottom $(25 \%)$ and upper (75\%) quartile. *Statistically significant difference from the untreated control ( $P<0.05$, Kruskal-Wallis test), $\checkmark$ Statistically significant difference between PAMAM and BCPAMAM treated cells ( $P<0.05$, Mann Whitney $U$ test).

estimates the pyridine nucleotide redox state in the cells and corresponds to metabolic changes (Abhishek et al., 2018; Berridge et al., 2005). BC-PAMAM was not toxic to mitochondria up to $50 \mu \mathrm{M}$ concentration.

\section{Apoptosis}

Induction of apoptosis was detected in cells treated for $24 \mathrm{~h}$ with PAMAM and BC-PAMAM at 5, 10 and $50 \mu \mathrm{M}$ concentration, as measured by the fluorescence reader and a confocal microscope using anti-PARP-1 antibodies (Asp 214) coupled with AlexaFluor 647. The results and representative microscopic images are shown in Fig. 2. One of the most important catalytic functions of the nuclear polymerase-1 poly-ADP-ribose (PARP-1) is the process of repairing damaged DNA. This enzyme is a substrate for the proteolytic activity of proteases involved in initiation of the apoptotic processes (caspases, calpains, cathepsins, granzymes and metalloproteinases). Specific products of this activity constitute a marker of the early stage of apoptosis, although they do not define its mechanism (Chaitanya et al., 2010). The small but significant increase in PARP-1 expression as an apoptotic marker induced by PAMAM was already observed at a concentration of $5 \mu \mathrm{M}$, while BC-PAMAM induced apoptotic changes at $10 \mu \mathrm{M}$. Signal from the apoptosis markers was significantly lower at all concentrations in cells treated with bioconjugate, particularly at the high $50 \mu \mathrm{M}$ concentration, which reveals a low pro-apoptotic effect of BC-PAMAM in HaCaT cells. 


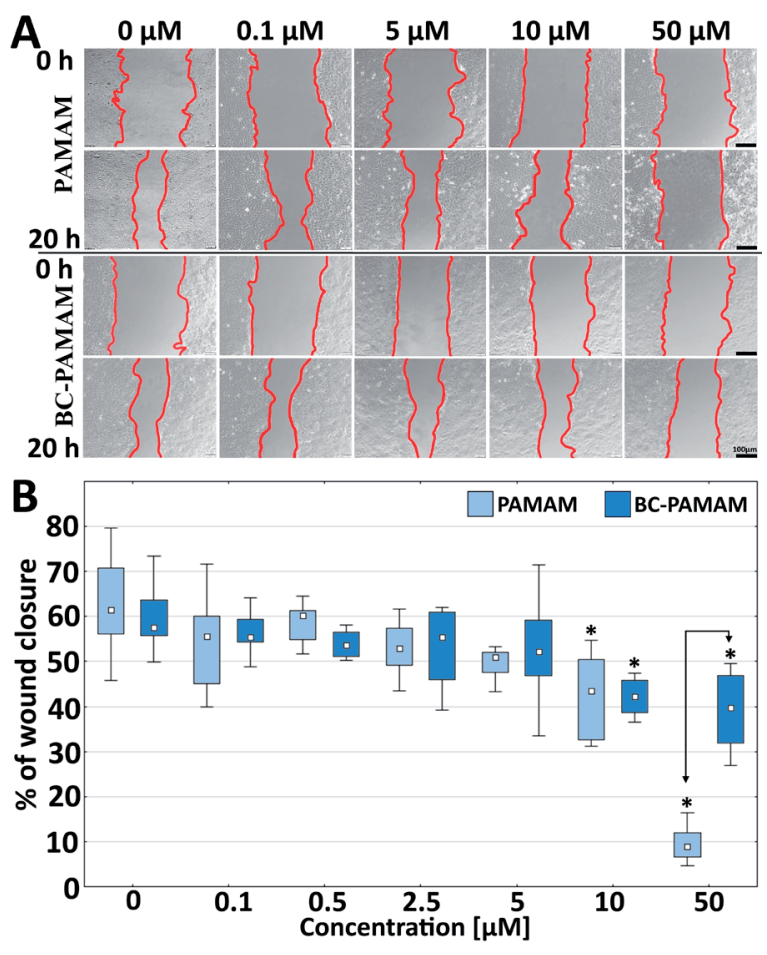

Figure 3. Effect of PAMAM and BC-PAMAM dendrimers on migration of $\mathrm{HaCaT}$ cells.

(A) Phase contrast microscope images were collected after scratching (upper rows) and after $20 \mathrm{~h}$ treatment with dendrimers (lower rows). (B) The images were analyzed using the ImageJ software. Results are presented as a percentage of the closing of the scratched surface and expressed as medians with error bars: bottom (25\%) and upper (75\%) quartile. *Significant differences against untreated control ( $P<0.05$, Kruskal-Wallis test), Arrows indicate signifficant difference between cells treated with PAMAM and BC-PAMAM $(P<0.05$, Mann Whitney $U$ test).

\section{Cell migration}

In cutaneous wound the healing skin cells migrate into the wound to restore the skin integrity. In order to determine the effect of dendrimers on $\mathrm{HaCaT}$ cell migration, a wound healing test was performed (Grada et al., 2017). After $20 \mathrm{~h}$ treatment of the $\mathrm{HaCaT}$ cells, both, the PAMAM and its bioconjugate had no significant effect on cell motility up to $5 \mu \mathrm{M}$ concentration (Fig. 3). Significant inhibitory effect was seen at $10 \mu \mathrm{M}$ of BCPAMAM and very high inhibition of cell migration was

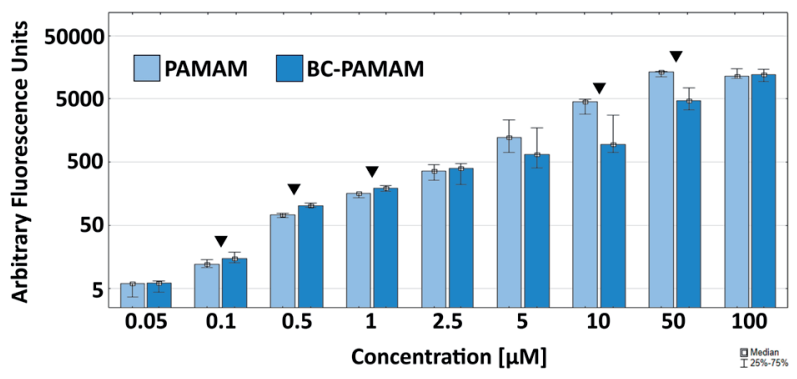

Figure 4. Intracellular accumulation of FITC-labeled PAMAM and BC-PAMAM in HaCaT cells after $24 \mathrm{~h}$.

Results are medians of relative fluorescence units from three replicates of four independent experiments. Error bars: bottom (25\%) and upper (75\%) quartile. $\nabla$ Significant difference between cellular PAMAM and BC-PAMAM fluorescence $(P<0.05$, Mann-Whitney $U$ test).

observed with $50 \mu \mathrm{M}$ PAMAM, which is in good agreement with advanced apoptosis under these conditions (Fig. 2).

\section{Cellular accumulation of PAMAM and BC-PAMAM}

Fluorescein isothiocyanate-labeled (FITC) PAMAM and BC-PAMAM were used to test the degree of intracellular accumulation of the studied dendrimers. The FITC fluorescence signal was measured after $24 \mathrm{~h}$ incubation with dendrimers (Fig. 4). Intracellular accumulation of native and conjugated dendrimers at concentrations ranging from 0.05 to $50 \mu \mathrm{M}$ revealed very similar pattern, with minor but significant differences. Up to $1 \mu \mathrm{M}$ concentrations of BC-PAMAM, its accumulation was significantly higher, whereas at $\geq 10 \mu \mathrm{M}$ concentrations more intracellular PAMAM was observed (Fig. 4). Mechanisms of biotin uptake in various cells have been investigated and it has been revealed that they depend on the external biotin concentration; passive diffusion takes place at high $(>25 \mu \mathrm{M})$ biotin concentrations, while two biotin transporting systems are involved at biotin concentrations below $5 \mu \mathrm{M}$. Two carriers transporting biotin into cells are the sodium-dependent multivitamin transporter (SMVT) and the proton-dependent monocarboxylate transporter 1 (MCT-1) (Daberkow et al., 2003; Grafe et al., 2003; Azhar et al., 2015). Valdapudi et al. (2012) considered feasibility of developing an SMVT targeted drug delivery systems. The results obtained here confirmed that $\mathrm{HaCaT}$ cells have efficient biotin transport-
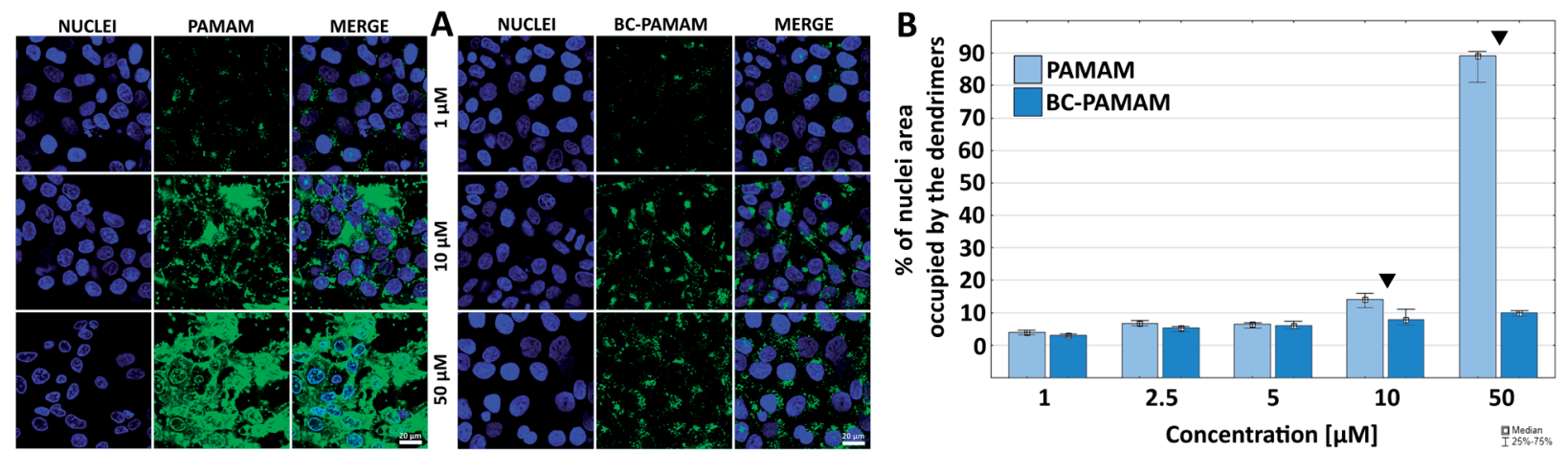

Figure 5. The penetration of FITC labeled PAMAM and BC-PAMAM dendrimers into the cell nuclei of HaCaT cells after $24 \mathrm{~h}$ incubation.

(A) Images were collected with confocal microscope: Fluorescence of labeled dendrimers (green signal) was recorded at $488 / 530$ nm, and DAPI labeled nuclei (blue signal) at $405 / 461 \mathrm{~nm}$. (B) Results expressed as a percentage of the overlap of labeled dendrimers with cell nuclei signals. Values are medians with error bars: bottom (25\%) and upper (75\%) quartiles. $\nabla$ Significant difference between PAMAM and BC-PAMAM $(P<0.05$, Mann-Whitney $U$ test). 

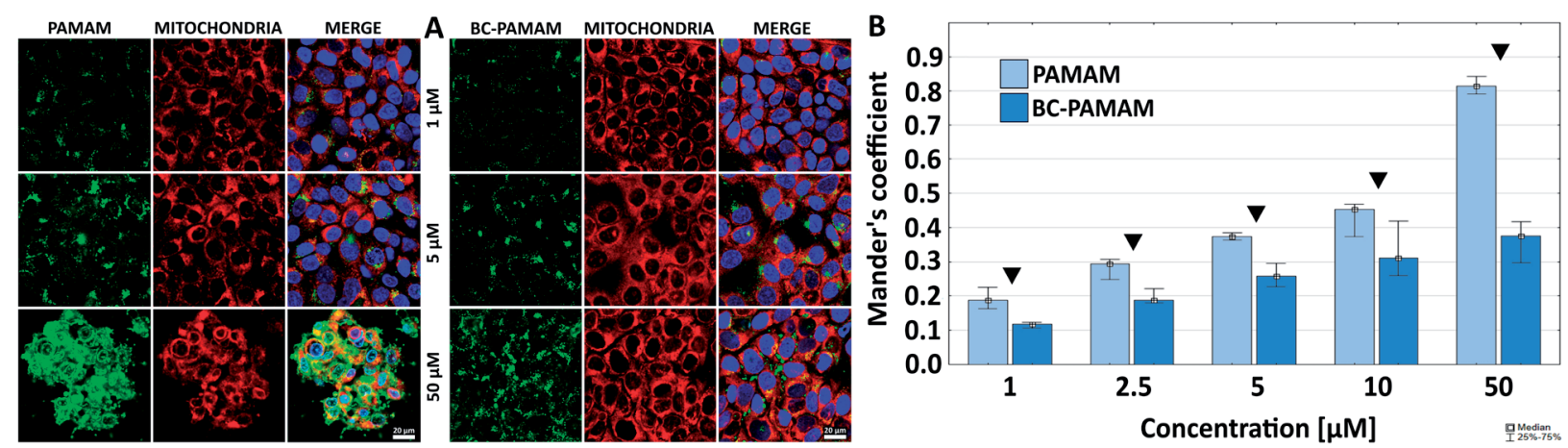

Figure 6. (A) Co-localization of FITC labeled PAMAM or BC-PAMAM dendrimers (green signal) and MitoTracker ${ }^{\circledR}$ Deep Red FM labeled mitochondria (red signal) in $\mathrm{HaCaT}$ cells after $24 \mathrm{~h}$ treatment. The images were collected with confocal microscopy, at $488 / 530 \mathrm{~nm}$ for FITC labeled dendrimers, 405/461 nm for DAPI and at $644 / 665 \mathrm{~nm}$ for mitochondria. (B) Images analyzed using ImageJ program. Results presented as Mander's coefficient, expressing the degree of the dendrimer overlap with the mitochondria signal. Values are medians with error bars: lower (25\%) and upper (75\%) quartile. $\nabla$ Significant difference between PAMAM and BC-PAMAM $(P<0.05$ MannWhitney U test).

ers delivering the biotin-conjugated dendrimers PAMAM G3 into cells at low external biotin concentrations.

\section{Subcellular localization of dendrimers}

We have studied the intracellular distribution of biotin conjugates by confocal microscopy. The following features were noticed:

Nuclei

The degree of penetration of FITC-labeled PAMAM and BC-PAMAM dendrimers into cell nuclei was tested after $24 \mathrm{~h}$ treatment. Figure 5 shows representative images from confocal microscopy and results of image analysis. Both dendrimers reveal very limited nuclei penetration (below 20\% of the nuclei area) at up to $10 \mu \mathrm{M}$ concentration. At all tested concentrations, the BC-PAMAM penetration remains significantly lower than that of PAMAM. At $50 \mu \mathrm{M}$ concentration, penetration of the nuclei by BC-PAMAM remains low, whereas PAMAM reaches $90 \%$ area, resulting in its high cytotoxic action.

Colocalization of dendrimers with mitochondria

The degree of colocalization of the dendrimers with mitochondria is presented in Fig. 6. Data, expressed as Mander's coefficients (mitochondrial signal overlapping FITC-PAMAM or FITC-BC-PAMAM signals), revealed a significantly lower localization of BC-PAMAM within the mitochondria when compared to the native PAMAM at all investigated dendrimer concentrations. This corroborates with the dendrimer cytotoxicity estimated with the XTT test evaluating mitochondrial metabolism activity. It is clearly visible at the confocal microscope images, that FITCBC-PAMAM signals are concentration-dependent and reached $\mathrm{M}=0.4$ at the cytotoxic $50 \mu \mathrm{M}$ concentration. Native FITC-PAMAM penetrates mitochondria to a higher degree and reaches $\mathrm{M}=0.9$ at the highest cytotoxic concentration.

Comparison of the XTT cytotoxicity test results and intracellular dendrimer penetration allows to conclude that in the PAMAM cytotoxicity in HaCaT cells is due to a relatively high mitochondrial co-localization rather than to the lysosomal damage, and that BCPAMAM is much less toxic for mitochondria at the corresponding concentrations. Our earlier studies had shown similar results concerning low cytotoxicity and a rather high mitochondrial localization of dendrimers in other types of human skin cell lines - normal BJ fibroblasts (BJ) and the squamous cell carcinoma (SCC15) (Uram et al., 2013; Uram et al., 2015). Localization of PAMAM and BC-PAMAM dendrimers was also in agreement with the data obtained by others for biotin alone. It has been shown that in the rat liver, the majority of labeled biotin accumulated in mitochondria and cytosol, with a small fraction in the microsomes (Petrelli et al., 1979; Zempleni et al., 2009). Nucleus of human lymphoid cells contains $0.7-1 \%$ of total biotin, depending on the cell proliferation state (Stanley et al., 2001).

\section{Production of proinflammatory cytokines IL-1 $a$ and TNF- $a$}

The effect of three recognized immune stimulants of the human keratinocytes, namely the E. coli LPS and GroEL protein (Graham et al., 2004) and the chemical substance PMA, on the pro-inflammatory cytokine production by $\mathrm{HaCaT}$ cells was investigated. The final concentrations of stimulants were comparable to those applied by others for primary human keratinocytes (LPS $100 \mathrm{ng} / \mathrm{ml}$, GroEL $1 \mu \mathrm{g} / \mathrm{ml}$ and PMS $50 \mathrm{ng} / \mathrm{ml})$. The duration of treatment was $12 \mathrm{~h}$. PMA was used as a negative control because it was recently found that this pro-carcinogenic and pro-inflammatory factor does not stimulate the $\mathrm{HaCaT}$ cells for IL-1 $\alpha$ production (Magcwebeba et al., 2012).

$\mathrm{HaCaT}$ cells stimulation with LPS caused 50\% increase in total IL-1 $\alpha$ level, and $70 \%$ increase was observed with GroEL, when compared to controls; no effect was seen with PMA (Fig 7). Treatment of nonstimulated $\mathrm{HaCaT}$ cells for $12 \mathrm{~h}$ with native PAMAM or BC-PAMAM at $1 \mu \mathrm{M}$ non-toxic concentrations indicated a significant inhibition in the total IL- $1 \alpha$ production, with a smaller but still significant effect of the bioconjugate. Low dendrimer concentration (0.1 $\mu \mathrm{M})$ did not affect the cytokine level (Fig 7).

Treatment of cells with dendrimers in the presence of stimulants induced different responses. In the presence of LPS, the total level of IL- $1 \alpha$ was significantly reduced below that of the untreated control by $1 \mu \mathrm{M}$ PAMAM, whereas BC-PAMAM reduced IL- $1 \alpha$ to the control level at that concentration. In the presence of GroEL, a significant reduction in the induced production of IL- $1 \alpha$ was caused by both types of dendrimers, with a smaller effect of the bioconjugate (35\% 

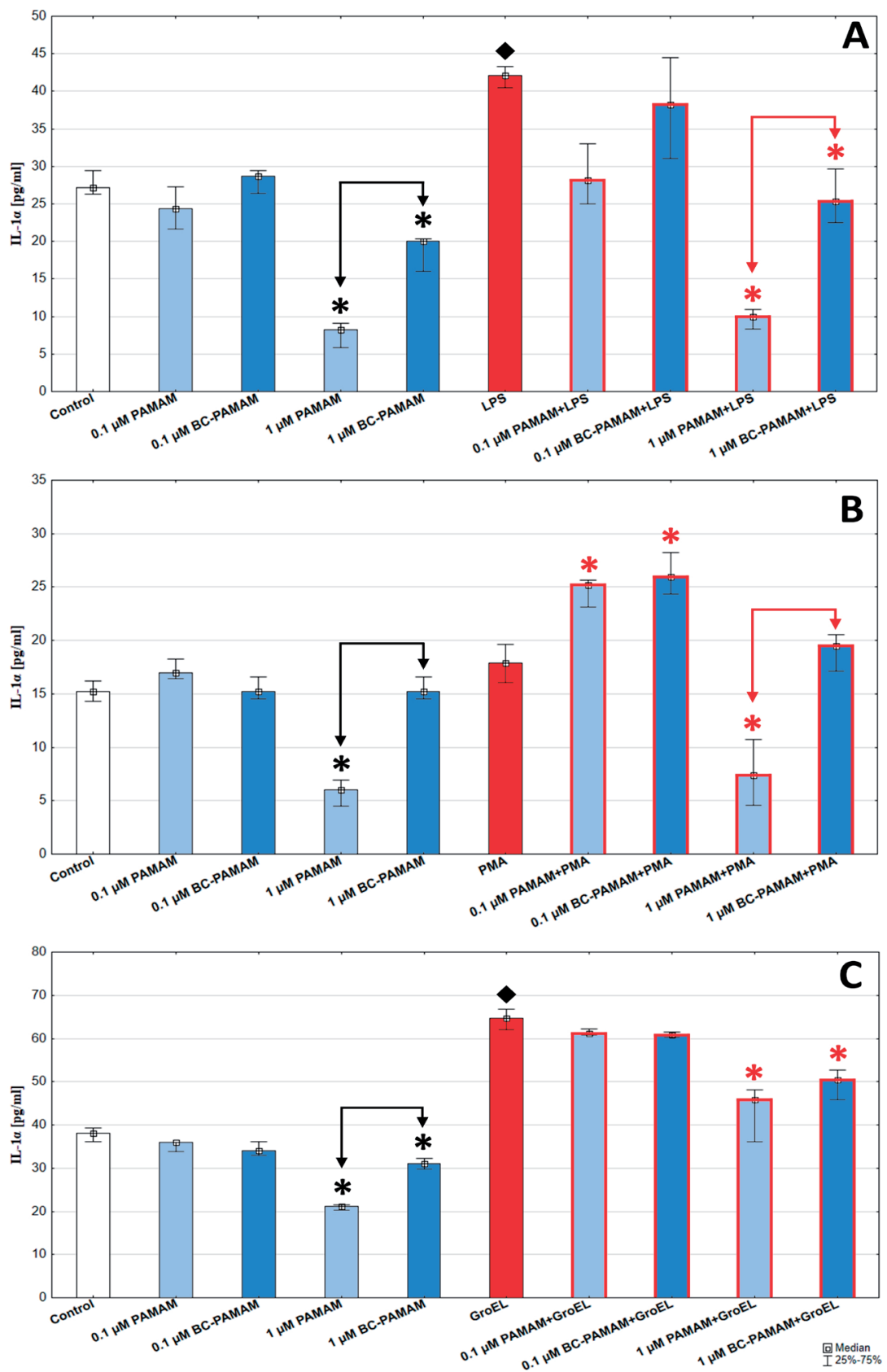

Figure 7. Effect of non-toxic PAMAM and BC-PAMAM concentrations on IL-1a production by HaCaT cells after $12 \mathrm{~h}$ treatment.

Cells were treated with dendrimers $(0.1$ and $1 \mu \mathrm{M})$ with and without stimulants: (A) LPS $(100 \mathrm{ng} / \mathrm{ml})$, (B) PMA (50 ng/ml) and (C) GroEL $(1 \mu \mathrm{g} / \mathrm{ml})$. Results are expressed as medians with error bars: bottom $(25 \%)$ and upper $(75 \%)$ quartile. *Significant difference between unstimulated/stimulated control and dendrimer treated $(P<0.05$, Kruskal-Wallis test), arrows: significant difference between cells treated with PAMAM and BC-PAMAM $(P<0.05$, Mann-Whitney $U$ test). $\diamond$ Significant difference between unstimulated and stimulated cells $(P<0.05$, Mann-Whitney U test).

and $25 \%$, respectively) (Fig. 7). The lack of stimulatory effect of PMS on HaCaT cells was studied by the others and the mechanism was explained as a deficiency that affects downstream signaling of the MEK/ERK pathway in these cells (Magcwebeba et al., 2012; Ridd et al., 2010). Unexpectedly, in the presence of PMS, lower concentrations of both types of dendrimers significantly increased the total IL- $1 \alpha$ level, whereas PAMAM resulted in a decrease in that cytokine level and BC-PAMAM had no effect at $1 \mu \mathrm{M}$ concentrations, when compared to the untreated control (Fig. 7).
At $1 \mu \mathrm{M}$ concentrations, both, the PAMAM and BC-PAMAM dendrimers clearly confirmed their antiinflammatory action against production of IL- $1 \alpha$ cytokine by $\mathrm{HaCaT}$ keratinocytes stimulated by LPS or GroEL. Immunosuppressive and anti-inflammatory properties of various types of dendrimers have been characterized (Ilinskaya \& Dobrovolskaia, 2014). However, comparative studies of the IL- $1 \alpha$ expression, a basic keratinocyte proinflammatory cytokine (Phillips et al., 1995; Feldmeyer et al., 2010), in normal human epidermal keratinocytes (NHK), spontaneously immortalized $\mathrm{HaCaT}$ and transformed by 
human papillomavirus (HPV) EK 16 and EK18 lines of keratinocytes revealed that they reacted differently after UVB-irradiation and/or treatment with CsA (Marionnet et al., 1997). Similarly, Pastore and others (Pastore et al., 2011) had documented that NHK and $\mathrm{HaCa} \mathrm{T}$ responded by different chemokine production under treatment with plant polyphenols at the constitutive, UVA-, LPS-, or TNF- $\alpha$-induced inflammatory responses. Also, Liu and others (Liu et al., 2012) described a different response of both types of keratinocytes to oxidative stress. On the other hand, studies by Colombo and others (Colombo et al., 2017) and others (Stein et al., 1997; Magcwebeba et al., 2012) had documented that HaCaT cells can be applied as a reliable model for in vitro inflammation studies and repair processes under optimal, controlled conditions. That includes specificity of the stimulating agent: UV light, allergens or irritants (Kim et al., 2012, Hoffman et al., 2013), carbon nanomaterials (Pelin et al., 2017), palmitic acid (Zhou et al., 2013), as well as cell density confluence/non-confluence (Shabo et al., 2001), and low/high calcium ion concentrations (Savignan et al., 2004; Borowiec et al., 2013).

The study of the effect of PAMAM and BCPAMAM dendrimers on $\mathrm{TNF}-\alpha$ production did not show any significant effects (results not shown). Unstimulated cells did not produce TNF- $\alpha$ and none of the tested stimulants increased that cytokine's production by $\mathrm{HaCaT}$ cells. All of the obtained results were below the threshold of the test's sensitivity $(6 \mathrm{pg} / \mathrm{ml})$. Primary keratinocytes are known to produce TNF- $\alpha$ in response to UV radiation, LPS (Köck et al., 1990; Bashir et al., 2009) or bacterial and fungal stimulation (Oizumi et al., 2014; Nakamura et al., 2002). Cheng et al. (2008) estimated the level of TNF- $\alpha$ produced by $\mathrm{HaCaT}$ cells as $<1 \mathrm{pg} / \mathrm{ml}$, and after stimulation with LPS for $48 \mathrm{~h}$ as $<3 \mathrm{pg} / \mathrm{ml}$. A significant production of TNF- $\alpha$ by HaCaT cells was described after stimulation by IFN- $\gamma$ (Zampetti et al., 2009) and by palmitic acid (Zhou et al., 2013). Recently, Udommethaporn et al. (2016) described a doxycycline-inducible TNF- $\alpha$ expression system in $\mathrm{HaCaT}$ keratinocytes in vitro. The lack of response observed in our experiments may be due to the observation that biotin deficiency up-regulates $T N F-\alpha$ production at the transcriptional level in a mouse in vivo model and in a murine macrophagelike cell line, J774.1, and that biotin excess may downregulate TNF- $\alpha$ production (Kuroishi et al., 2008). Supplementation of biotinylated dendrimers may induce that effect.

\section{IN SUMMARY}

Functionalization of the PAMAM G3 dendrimer with amide-linked 9 biotin molecules and aldiminelinked 10 molecules of pyridoxal phosphate (BCPAMAM) had significantly decreased its cytotoxicity to $50 \mu \mathrm{M}$ concentration as tested by two viability assays (NR and XTT) in the HaCaT keratinocytes, when compared to the non-substituted dendrimer PAMAM G3. BC-PAMAM accumulates in $\mathrm{HaCaT}$ cells with high efficiency in a concentration-dependent manner, however, its mitochondrial localization is substantially lower than native PAMAM, which correlates with their cytotoxicity. Also, active apoptosis was kept at a low level at up to $50 \mu \mathrm{M}$ concentration of the conjugate. The only undesirable, but significantly inhibitory effect on cell mobility was observed at $10 \mu \mathrm{M}$ BC-
PAMAM. However, the important anti-inflammatory action of BC-PAMAM was clearly documented by evaluation of the decreased production of total IL- $1 \alpha$ in bacterial antigen (LPS and GroEL) unstimulated and stimulated cells. Thus, BC-PAMAM was demonstrated as a potential carrier for safe delivery of vitamins into the epidermis.

\section{Acknowledgements}

We gratefully acknowledge Prof. Stanislaw Orkisz from the University of Rzeszow, for kindly enabling us to perform measurements using the confocal microscope.

\section{REFERENCES}

Abdallah F, Mijouin L, Pichon C (2017) Skin immune landscape: inside and outside the organism. Mediators of Inflammation 2017: Article ID 5095293. https://doi.org/10.1155/2017/5095293

Abhishek K, Divya J, Kavita S, Renuka D, Mittal MS, Pandey AK (2018) Models and methods for in vitro toxicity, in In Vitro Toxicology. Chapter 3. pp 45-65, Academic Press

Azhar A, Booker GW, Polyak SW (2015) Mechanisms of Biotin Transport. Biochem Anal Biochem 4: 210. doi:10.4172/2161-1009.1000210

Bashir MM, Sharma MR, Werth VP (2009) TNF-alpha production in the skin. Arch Dermatol Res 301: 87-91. https://doi.org/10.1007/ s00403-008-0893-7

Berridge MV, Herst PM, Tan AS (2005) Tetrazolium dyes as tools in cell biology: New insights into their cellular reduction. Biotech Ann Rev 11: 127-152. https://doi.org/10.1016/S1387-2656(05)11004-7

Borowiec AS, Delcourt P, Dewailly E, Bidaux G (2013) Optimal differentiation of in vitro keratinocytes requires multifactorial external control. PLoS One 8: e77507. https://doi.org/10.1371/journal. pone.0077507

Chaitanya GV, Alexander JS, Babu PP (2010) PARP-1 cleavage fragments: signatures of cell-death proteases in neurodegeneration. Cell Commun Signal 8: 31. https://doi.org/10.1186/1478-811X-8-31

Cheng HM, Hsiang CY, Chen GW, Wu SL, Chen JC, Huang CY, Bau DT, Ho TY (2008) Inhibition of lipopolysaccharide-induced interleukin-1beta and tumor necrosis factor-alpha production by menthone through nuclear factor-kappaB signaling pathway in $\mathrm{HaCat}$ cells. Chin I Physiol 51: 160-166

Colombo I, Sangiovanni E, Maggio R, Mattozzi C, Zava S, Corbett Y, Fumagalli M, Carlino C, Corsetto PA, Scaccabarozzi D, Calvieri S, Gismondi A, Taramelli D, Dell'Agli M (2017) HaCaT Cells as a reliable in vitro differentiation model to dissect the inflammatory/repair response of human keratinocytes. Mediators Inflamm 2017: 7435621. https://doi.org/10.1155/2017/7435621

Daberkow RL, White BR, Cederberg RA, Griffin JB, Zempleni J (2003) Monocarboxylate transporter 1 mediates biotin uptake in human peripheral blood mononuctear cells. J Nutr 33: 2703-2706. DOI: $10.1093 /$ jn/133.9.2703

Depeint F, Bruce WR, Shangari N, Mehta R, O’Brien PJ (2006a) Mitochondrial function and toxicity: role of the $\mathrm{B}$ vitamin family on mitochondrial energy metabolism. Chem Biol Interact 63: 94-112. https://doi.org/10.1016/j.cbi.2006.04.014

Depeint F, Bruce WR, Shangari N, Mehta R, O’Brien PJ (2006b) Mitochondrial function and toxicity: role of $\mathrm{B}$ vitamins on the onecarbon transfer pathways. Chem Biol Interact 163: 113-132. https:// doi.org/10.1016/j.cbi.2006.05.010

Dianzani C, Zara GP, Maina G, Pettazzoni P, Pizzimenti S, Rossi F, Gigliotti CL, Ciamporcero ES, Daga M, Barrera G (2014) Drug delivery nanoparticles in skin cancers. Biomed Res Int 2014: 895986. https://doi.org/10.1155/2014/895986

Dombrowski Y, Peric M, Koglin S, Kammerbauer C, Göß C, Anz D, Simanski M, Gläser R, Harder J, Hornung V, Gallo RL, Ruzicka T, Besch R, Schauber J (2011) Cytosolic DNA triggers inflammasome activation in keratinocytes in psoriatic lesions. Sci Transl Med 3: 82ra38. https://doi.org/10.1126/scitranslmed.3002001

Emerit I, Cerutti PA (1981) Tumour promoter phorbol-12-myristate13-acetate induces chromosomal damage via indirect action. Nature 293: $144-146$

Feldmeyer L, Werner S, French LE, Beer HD (2010) Interleukin-1, inflammasomes and the skin. Eur J Cell Biol 89: 638-644. https://doi. org/10.1016/j.ejcb.2010.04.008

Filipowicz A, Wołowiec S (2011) Solubility and in vitro transdermal diffusion of riboflavin assisted by PAMAM dendrimers. Int $J$ Pharm 408: 152-156. https://doi.org/10.1016/j.ijpharm.2011.01.033

Grada A, Otero-Vinas M, Prieto-Castrillo F, Obagi Z, Falanga V (2017) Research techniques made simple: analysis of collective cell migration using the wound healing assay. J Invest Dermatol 137: e11e16. https://doi.org/10.1016/j.jid.2016.11.020 
Grafe F, Brandsch M, Wohlrab W, Neubett RH, Brandsch M. (2003) Transport of biotin in human keratinocytes. I Invest Dermatol 120: 428-433. doi: http://dx.doi.org/10.1046/j.1523-1747.2003.12058.x

Graham GM, Farrar M.D, Cruse-Sawyer JE, Holland KT, Ingham E (2004) Proinflammatory cytokine production by human keratinocytes stimulated with propionibacterium Acnes and P. Acnes GroEL. Brit I Dermatol 150: 421-428. https://doi.org/10.1046/ j.1365-2133.2004.05762.x

Gröne A (2002) Keratinocytes and cytokines. Vet Immunol Immunopathol 88: $1-12$

Gutowska-Owsiak D, Ogg GS (2012) The epidermis as an adjuvant. J Invest Dermatol 132: 940-948. https://doi.org/10.1038/jid.2011.398

Hoffmann MK, Schmidt TJ (2013) Keratinocytes as effectors in allergic contact dermatitis towards sesquiterpene lactones - Different behavior of HaCaT and NHEK cells. Planta Med 79 - SL19. https://doi.org/10.1055/s-0033-1351845

Honda T, Kabashima K (2016) Novel concept of iSALT (inducible skin-associated lymphoid tissue) in the elicitation of allergic contact dermatitis. Proc Jpn Acad Ser B Phys Biol Sci 92: 20-28. https://doi. org/10.2183/pjab.92.20

Ilinskaya AN, Dobrovolskaia MA (2014) Immunosuppressive and antiinflammatory properties of engineered nanomaterials. $\mathrm{Br} J$ Pharmacol 171: 3988-4000. https://doi.org/10.1111/bph.12722

Imokawa G, Nakajima H, Ishida K (2015) Biological mechanisms underlying the ultraviolet radiation-induced formation of skin wrinkling and sagging II: over-expression of neprilysin plays an essential role. Int J Mol Sci 16: 7776-7795. https://doi.org/10.3390/ijms16047776

Jędrych M, Borowska K, Galus R, Jodłowska-Jędrych B (2014) The evaluation of the biomedical effectiveness of poly(amido)amine dendrimers generation 4.0 as a drug and as drug carriers: a systematic review and meta-analysis. Int J Pharm 462: 38-43. https://doi. org/10.1016/j.ijpharm.2013.12.033

Karimkhani C, Boyers LN, Dellavalle RP, Weinstock MA (2015) It's time for "keratinocyte carcinoma" to replace the term "nonmelanoma skin cancer". J Am Acad Dermatol 72: 186-187. https://doi. org/10.1016/j.jaad.2014.09.036

Kim DH, Byamba D, Wu WH, Kim TG, Lee MG (2012) Different characteristics of reactive oxygen species production by human keratinocyte cell line cells in response to allergens and irritants. Exp Dermatol 21: 99-103. https://doi.org/10.1111/j.16000625.2011.01399.x

Köck A, Schwarz T, Kirnbauer R, Urbanski A, Perry P, Ansel JC, Luger TA (1990) Human keratinocytes are a source for tumor necrosis factor. evidence for, synthesis and release upon stimulation with endotoxin or ultraviolet light. J Exper Med 172: 1609-1614

Köllisch G, Kalali BN, Voelcker V, Wallich R, Behrendt H, Ring J, Bauer S, Jakob T, Mempel M, Ollert M (2005) Various members of the Toll-like receptor family contribute to the innate immune response of human epidermal keratinocytes. Immunology 114: 531-541. https://doi.org/10.1111/j.1365-2567.2005.02122.x

Komine M (2009) Analysis of the mechanism for the development of allergic skin inflammation and the application for its treatment: keratinocytes in atopic dermatitis - their pathogenic involvement. $J$ Pharmacol Sci 110: 260-264

Kothapalli N, Camporeale G, Kueh A, Chew YC, Oommen AM, Griffin JB, Zempleni J (2005) Biological functions of biotinylated histones. J Nutr Biochem 16: 446-448. https://doi.org/10.1016/j.jnutbio.2005.03.025

Kuroishi T, Endo Y, Muramoto K, Sugawara S (2008) Biotin deficiency up-regulates TNF-alpha production in murine macrophages. J Leukoc Biol 83: 912-920. https://doi.org/10.1189/jlb.0607428

Labieniec-Watala M, Watala C (2015) PAMAM dendrimers: destined for success or doomed to fail? Plain and modified PAMAM dendrimers in the context of biomedical applications. J Pharm Sci 104: 2-14. https://doi.org/10.1002/jps.24222.

Lepe-Zuniga JL, Gery I (1984) Production of intra- and extracellular interleukin-1 (IL-1) by human monocytes. Clin Immunol Immunopathol 31: $222-230$

Li Y, Malkaram SA, Zhou J, Zempleni J (2014) Lysine biotinylation and methionine oxidation in the heat shock protein HSP60 synergize in the elimination of reactive oxygen species in human cell cultures. J Nutr Biochem 25: 475-482. https://doi.org/10.1016/j.jnutbio.2013.12.008

Liu L, Xie H, Chen X, Shi W, Xiao X, Lei D, Li J (2012) Differential response of normal human epidermal keratinocytes and HaCaT cells to hydrogen peroxide-induced oxidative stress. Clin Exp Dermatol 37: 772-780. https://doi.org/10.1111/j.1365-2230.2011.04315.x

Magcwebeba T, Riedel S, Swanevelder S, Bouic P, Swart P, Gelderblom W (2012). Interleukin- $1 \alpha$ induction in human keratinocytes $(\mathrm{HaCaT})$ : An in vitro model for chemoprevention in skin. J Skin Cancer 2012: 393681. https:/ / doi.org/10.1155/2012/393681

Maiti S, Paira P (2018) Biotin conjugated organic molecules and proteins for cancer therapy: A review. Eur J Med Chem 145: 206-223. https://doi.org/10.1016/i.ejmech.2018.01.001

Mann ER, McCarthy NE, Peake ST, Milestone AN, Al-Hassi HO, Bernardo D, Tee CT, Landy J, Pitcher MC, Cochrane SA, Hart
AL, Stagg AJ, Knight SC (2012) Skin- and gut-homing molecules on human circulating $\gamma \delta \mathrm{T}$ cells and their dysregulation in inflammatory bowel disease. Clin Exp Immunol 170: 122-130. https://doi. org/10.1111/j.1365-2249.2012.04649.x

Marcatili A, Cipollaro de l'Ero G, Galdiero M, Folgore A, Petrillo G (1997) TNF-alpha, IL-1 alpha, IL-6 and ICAM-1 expression in human keratinocytes stimulated in vitro with Escherichia coli heat-shock proteins. Microbiology 143: 45-53. https://doi.org/10.1099/00221287143-1-45

Marionnet AV, Chardonnet Y, Viac J, Schmitt D (1997) Differences in responses of interleukin-1 and tumor necrosis factor alpha production and secretion to cyclosporin-A and ultraviolet B-irradiation by normal and transformed keratinocyte cultures. Exp Dermatol 6: 22-28

Nakamura Y, Kano R, Hasegawa A, Watanabe S (2002) Interleukin-8 and tumor necrosis factor alpha production in human epidermal keratinocytes induced by Trichophyton mentagrophytes. Clin Diagn Lab Immunol 9: 935-937. https://doi.org/10.1128/CDLI.9.4.935-937.2002

Nestle FO, Di Meglio P, Qin J-Z, Nickoloff BJ (2009) Skin immune sentinels in health and disease. Nat Rev Immunol 9: 679-691. https://doi.org/10.1038/nri2622

Nizioł J, Uram E, Szuster M, Sekuła J, Ruman T (2015) Biological activity of $\mathrm{N}(4)$-boronated derivatives of 2'-deoxycytidine, potential agents for boron-neutron capture therapy. Bioorg Med Chem 23: 6297-6304. https://doi.org/10.1016/j.bmc.2015.08.026

Oizumi A, Nakayama H, Okino N, Iwahara C, Kina K, Matsumoto R, Hideoki O, Kenji T, Makoto I, Yasushi S, Kazuhisa I (2014) Pseudomonas-derived ceramidase induces production of inflammatory mediators from human keratinocytes via sphingosine-1-phosphate. PLOS ONE 9: e89402. https://doi.org/10.1371/journal. pone.0089402

Pålsson-McDermott EM, O’Neill LA (2004) Signal transduction by the lipopolysaccharide receptor, Toll-like receptor-4. Immunology 113: 153-162. https://doi.org/10.1111/j.1365-2567.2004.01976.x

Pastore S, Lulli D, Potapovich AI, Fidanza P, Kostyuk VA, Dellambra E, De Luca C, Maurelli R, Korkina LG (2011) Differential modulation of stress-inflammation responses by plant polyphenols in cultured normal human keratinocytes and immortalized $\mathrm{Ha}$ CaT cells. I Dermatol Sci 63: 104-114. https://doi.org/10.1016/j. jermsci.2011.04.011

Pelin M, Fusco L, León V, Martín C, Criado A, Sosa S, Vázquez E, Tubaro A, Prato M (2017) Differential cytotoxic effects of graphene and graphene oxide on skin keratinocytes. Sci Rep 7: 40572. https:// doi.org/10.1038/srep40572

Petrelli F, Moretti P, Paparelli M (1979) Intracellular distribution of biotin-14COOH in rat liver. Mol Biol Rep 4: 247-252

Phillips WG, Feldmann M, Breathnach SM, Brennan FM (1995) Modulation of the IL-1 cytokine network in keratinocytes by intracellular IL-1 alpha and IL-1 receptor antagonist. Clin Exp Immunol 101: $177-182$

Ridd K, Dhir S, Smith AG, Gant TW (2010). Defective TPA signalling compromises $\mathrm{HaCat}$ cells as a human in vitro skin carcinogenesis model. Toxicol In Vitro 24: 910-915. https://doi.org/10.1016/j. tiv.2009.11.017

Savignan F, Ballion B, Odessa MF, Charveron M, Bordat P, Dufy B (2004) Mitochondrial membrane potential (DeltaPsi) and $\mathrm{Ca}(2+)$ induced differentiation in HaCaT keratinocytes. J Biomed Sci 11: 671682. https://doi.org/10.1159/000079680

Stanley JS, Griffin JB, Zempleni J (2001) Biotinylation of histones in human cells. Effects of cell proliferation. Eur J Biochem 268: 5424 5429

Stein M, Bernd A, Ramirez-Bosca A, Kippenberger S, Holzmann H (1997) Measurement of anti-inflammatory effects of glucocorticoids on human keratinocytes in vitro. Comparison of normal human keratinocytes with the keratinocyte cell line HaCaT. Arzneimittelforschung 47: 1266-1270

Szabo I, Wetzel MA, Rogers TJ (2001) Cell-density-regulated chemotactic responsiveness of keratinocytes in vitro. I Invest Dermatol 117: 1083-1090. https://doi.org/10.1046/j.0022-202x.2001.01546.x

Udommethaporn S, Tencomnao T, McGowan EM, Boonyaratanakornkit V (2016) Assessment of anti-TNF- $\alpha$ activities in keratinocytes expressing inducible TNF- $\alpha$ : a novel tool for anti-TNF- $\alpha$ drug screening. PLOS ONE 11: e0159151. https://doi.org/10.1371/journal.pone. 0159151

Uram L, Szuster M, Filipowicz A, Gargasz K, Wołowiec S, WałajtysRode E (2015) Different pattern of the nuclear and mitochondrial penetration by the PAMAM G3 dendrimer and its biotin-pyridoxal bioconjugate BC-PAMAM G3 in normal and cancer cells in vitro. Int J Nanomed 10: 5647-5661. https://doi.org/10.2147/IJN.S87307

Uram L, Szuster M, Gargasz K, Filipowicz A, Wałajtys-Rode E, Wolowiec S (2013) In vitro cytotoxicity of the ternary PAMAM G3-pyridoxal-biotin bioconjugate. Int J Nanomedicine 8: 4707-4720. https://doi.org/10.2147/IJN.S53254

Uram \&, Szuster M, Misiorek M, Filipowicz A, Wołowiec S, WałajtysRode E (2017) The effect of G3 PAMAM dendrimer conjugated with B-group vitamins on cell morphology, motility and ATP level 
in normal and cancer cells. Eur J Pharm Sci 102: 275-283. https:// doi.org/10.1016/j.ejps.2017.03.022

Vadlapudi AD, Vadlapatla RK, Mitra AK (2012) Sodium dependent multivitamin transporter (SMVT): a potential target for drug delivery. Curr Drug Targets 13: 994-1003

van Eden W, Koets A, van Kooten P, Prakken B, van der Zee R (2003) Immunopotentiating heat shock proteins: negotiators between innate danger and control of autoimmunity. V accine 21: 897901

Yang W, Cheng Y, Xu T, Wang X, Wen L-p (2009) Targeting cancer cells with biotin-dendrimer conjugates Eur J Med Chem 44: 862-868. https://doi.org/10.1016/j.ejmech.2008.04.021

Zampetti A, Mastrofrancesco A, Florji E, Maresca V, Picardo M, Amerio P, Felician C (2009) Proinflammatory cytokine production in
HaCat cells treated by eosin: implications for the topical treatment of psoriasis. Int J Immunopathol Pharmacol 22: 1067-1075. https://doi. org/10.1177/039463200902200423

Zempleni J (2005) Uptake, localization, and noncarboxylase roles of biotin. Annu Rev Nutr 25: 175-196. https://doi.org/10.1146/annurev. nutr.25.121304.131724

Zempleni J, Wijeratne SS, Hassan YI (2009) Biotin. Biofactors 35: 36-46. https://doi.org/10.1002/biof.8

Zhou B-r, Zhang J-a, Zhang Q, Permatasari F, Xu Y, Wu D, Zhiqiang Yin Z-q, Luo D (2013) Palmitic acid induces production of proinflammatory cytokines interleukin-6, interleukin-1 $\beta$, and tumor necrosis factor- $\alpha$ via a NF- $x \mathrm{~B}$-dependent mechanism in HaCaT keratinocytes. Hindawi Publishing Corporation. Mediators of Inflammation 2013, Article ID 530429. https://doi.org/10.1155/2013/530429 